\title{
Pathogenicity and Immunity Studies of Haemophilus Parasuis Serotypes
}

\author{
By R. Nielsen
}

National Veterinary Laboratory, Copenhagen, Denmark.

\begin{abstract}
Nielsen, R.: Pathogenicity and immunity studies of Haemophilus parasuis serotypes. Acta vet. scand. 1993, 193-198. - After intranasal inoculation of SPF pigs with the 7 reference strains of Haemophilus parasuis only the reference strains of serotypes 1 and 5 proved to be pathogenic and were able to produce the lesions characteristic of Glässer's disease. Even though the reference strains of serotypes 2, 3, 4,6 and 7 proved to be apathogenic, intranasal inoculation resulted in the development of circulating antibodies as demonstrated by the complement fixation test. This serological response suggests an antigenic relationship between serotypes 1 and 3 different from the relationship seen among serotypes 2, 4, 5, 6 and 7 . Pigs given an aerosol with the apathogenic serotypes 2, 3, 4 and 7, respectively, resisted challenge with a virulent Danish strain of serotype 5. These results indicate that the 7 serotypes also have antigenic determinants in common and that these determinants elicit cross-protecting immunity on the respiratory mucosa.
\end{abstract}

Glässer's disease; serological response; cross immunity.

\section{Introduction}

Haemophilus parasuis (Biberstein \& White 1969 ) is the causative agent of Glässer's disease, a syndrome in pigs which is characterized by fibrinous polyserositis, polyarthritis and meningitis (Glässer 1910). In recent years, the disease has acquired increasing importance in some countries where modern production systems have been adopted by the pig industry. Thus, specific pathogen free (SPF) herds have suffered acute outbreaks with a high mortality and morbidity rate (Baehler et al. 1974, Nielsen \& Danielsen 1975, Miniats et al. 1986).

It is generally assumed that the immune status of the pig and stress such as transport are important factors in the pathogenesis of Glässer's disease. However, recent observations have indicated differences in virulence among $H$ parasuis strains. Morozumi \& Nicolet (1986a) and Nicolet et al. (1986) defined 7 serotypes (1-7) from agar gel precipitation tests and agglutinability in acriflavine and described 2 different electrophoretic patterns, (PAGE type I and II) among SDS-solubilized whole cells. These various tests indicated that most isolates from lesions were non-capsulated and belonged to PAGE type II.

In the present investigation the pathogenicity of the 7 reference strains of the respective serotypes of $H$ parasuis was studied using intranasal inoculation in 8-week-old SPF pigs. The serological and clinical response to inoculation and immunity to re-inoculation were investigated using a Danish serotype 5 strain for challenge.

\section{Material and methods}

\section{Bacterial strains}

The reference strains of the serotypes of $H$. parasuis used for inoculation of pigs were: 
Serotype 1 (No 4), serotype 2 (SW140), serotype 3 (SW114), serotype 4 (SW124), serotype 5 (Nagasaki), serotype 6 (131), and serotype 7 (174). The strains were kindly provided by Prof. J. Nicolet, University of Berne. A Danish strain, 4800, isolated from a case of Glässer's disease and belonging to serotype 5, was used for challenge.

\section{Inoculation of pigs}

Inoculations were made either by the intranasal route or by aerosol. The organisms were grown for $18 \mathrm{~h}$ on modified PPLO agar (Nicolet 1971) and harvested with phosphate-buffered saline, $\mathrm{pH}$ 7.2. The density of the suspension was adjusted by reference to $\mathrm{Mc}$ Farland tube No. 10 to approximately $3 \times 10^{9}$ organisms per ml. Five $\mathrm{ml}$ of this suspension were instilled intranasally with a syringe while the head of the pig was held in a raised position or were given as an aerosol (Microjet 109, Defensor AG, Zürich).

\section{Animals}

The 23 eight week old pigs used were obtained from the herd which is maintained as an SPF unit at the NVL. $H$. parasuis has never been isolated from this herd and antibody titres to the organism have not been observed using the complement-fixation test (CFT) on serum samples from the herd.

\section{Experiment 1}

Fourteen pigs (No 1-14) were divided into 7 groups with 2 pigs in each. Each group was inoculated intranasally with 1 of the 7 serotypes. During and after inoculation the groups were kept isolated from one another in separate units. The pigs were killed 3 weeks after inoculation.

\section{Experiment 2}

Eight pigs (No 15-22) were divided into 4 groups of 2. The groups were also kept isolated and given an aerosol containing serotypes $2,3,4$ or 7, respectively. A ninth pig (No 23) was not given an aerosol but kept as a control for the challenge with strain 4800 . Two weeks after exposure to the aerosol, each pig was challenged intranasally with $5 \mathrm{ml}$ of a suspension of strain 4800 containing approximately $0.3 \times 10^{10}$ organisms per $\mathrm{ml}$. The pigs were killed 5 days later.

\section{Post-mortem examination}

All pigs were subjected to a full post-mortem examination. Specimens for bacteriological examination were taken from the pleura, pericardium, lungs, tonsils, nasal cavity, liver, spleen, meninges and joints and inoculated on 5 per cent calf blood agar, with an $E$. coli streaked diagonally across the plates as a "feeder" bacterium. Incubation was at $37^{\circ} \mathrm{C}$ for $18 \mathrm{~h}$.

\section{Serological examination}

Blood samples were collected before inoculation, before challenge and at death and the serum examined by the modified CFT (Casey 1965 , Nielsen 1982) for antibodies to $H$. parasuis serotype 1-7.

The antigens for the CFT were $18 \mathrm{~h}$ cultures on modified PPLO agar of the 7 serotype strains, which were harvested in saline containing 1:20,000 merthiolate, sedimented by centrifugation ( $3000 \mathrm{x}$ g at $4 \mathrm{C}$ for $15 \mathrm{~min}$ ) and resuspended in 0.9 per cent saline with merthiolate. Sera were heated at $60^{\circ} \mathrm{C}$ for $30 \mathrm{~min}$ before testing. Normal, unheated serum from young pigs free from $H$. parasuis infection was used in a dilution of 1:150 in veronal-buffered gelatine-water solution ( $\mathrm{pH} \mathrm{7.4)}$ as the reconstituting fluid for lyophilized, guinea pig complement. Five 50 per cent haemolytic units were used in the test. The end-point of a titration was the highest dilution of serum showing 
30 per cent haemolysis or less compared with haemoglobin colour standards (ranging from 0-100 per cent haemolysis).

\section{Results}

\section{Experiment 1}

Clinical findings. The 2 pigs (No 1 and 2) inoculated with serotype 1 became anorectic day 2 after inoculation (p.i.). Pig No 2 later became dyspneic and recumbent. It was treated with Streptocillin ${ }^{\circledR}$ vet (Novo) and improved. Pig No 1 recovered without treatment. Pig No 9 , which was inoculated with serotype 5 , was anorectic day 5 and 6 p.i. but recovered afterwards. Pig No 10, which was also inoculated with serotype 5, became anorectic and recumbent day 2 p.i. and developed swollen joints the following day. Although it was treated on 3 successive days it improved only transiently and was killed day 6 p.i. None of the pigs inoculated with serotypes $2,3,4,6$ or 7 showed any signs of disease.

Pathological findings. Necropsy day 21 p.i. revealed a fibrous pleuritis in pig No 1 , a fibrous pleuritis, pericarditis and peritonitis in pig No 2 and a fibrous pericarditis and excess of synovial fluid in the joint cavities of pig No 9. In pig No 10 killed day 6 p.i., there was a serofibrinous pericarditis and serosanguinous fluid in the hock joint cavities. No other pig had any macroscopic lesions at necropsy.

Bacteriological findings. $\mathrm{H}$ parasuis was not re-isolated from any pig.

Serological findings. All pigs were seronegative before inoculation. At the time when necropsied No 1 and 2, inoculated with serotype 1, had homologous titres of 1:64 (Table 1 ), while the titres to serotype 3 were $1: 16$. Antigens of the other serotypes did not react with these 2 sera. Pig No 5 and 6, inoculated with serotype 3 , had homologous titres of 1:16. Heterologous titres were only seen with serotype 1 antigen (1:32). Pig No 10, inoculated with serotype 5 and killed day 6 p.i. had not developed antibodies (omitted in Table 1), whereas its fellow, No 9, killed after 3 weeks, had a homologous titre of 1:16 and heterologous titres of 1:8 to $1: 16$ to serotypes 2,4 , 6 and 7. The pigs inoculated with serotypes 2 , 4,6 or 7 , respectively, had homologous titres of $1: 16$ and heterologous titres of $1: 8$ to $1: 16$ to the other serotypes except 1 and 3 .

\section{Experiment 2}

Clinical findings. The 8 pigs (No 15-22) given an aerosol containing one or other of serotypes 2, 3, 4 and 7 did not show any clinical signs. Challenge of these pigs with strain 4800 (serotype 5) did not result in any clinical disease. However, pig No 23, which was a con-

Table 1. Homologous and heterologous CFT titres in pigs experimentally inoculated intranasally with reference serotypes 1 to 7 of $\mathrm{H}$ parasuis.

\begin{tabular}{lcrrrrrrr}
\hline \multirow{2}{*}{$\begin{array}{l}\text { Sera } \\
\text { from }\end{array}$} & $\begin{array}{c}\text { Inoculated } \\
\text { with }\end{array}$ & \multicolumn{6}{c}{ Antigen from serotype: } \\
\cline { 3 - 9 } Pig. No & serotype & 1 & 2 & 3 & 4 & 5 & 6 & 7 \\
\hline 1 & 1 & $* 64$ & 0 & 16 & 0 & 0 & 0 & 0 \\
2 & 1 & 64 & 0 & 16 & 0 & 0 & 0 & 0 \\
3 & 2 & 0 & 16 & 0 & 8 & 8 & 0 & 8 \\
4 & 2 & 0 & 16 & 0 & 8 & 8 & 0 & 8 \\
5 & 3 & 32 & 0 & 16 & 0 & 0 & 0 & 0 \\
6 & 3 & 32 & 0 & 16 & 0 & 0 & 0 & 0 \\
7 & 4 & 0 & 16 & 0 & 16 & 8 & 0 & 16 \\
8 & 4 & 0 & 16 & 0 & 16 & 8 & 0 & 16 \\
9 & 5 & 0 & 16 & 0 & 8 & 16 & 16 & 8 \\
11 & 6 & 0 & 8 & 0 & 8 & 8 & 16 & 8 \\
12 & 6 & 0 & 8 & 0 & 8 & 8 & 16 & 8 \\
13 & 7 & 0 & 16 & 0 & 8 & 8 & 8 & 16 \\
14 & 7 & 0 & 16 & 0 & 8 & 8 & 8 & 16 \\
\hline
\end{tabular}

No 10 , killed day 6 p.i., had not developed detectable antibodies.

*Titres are given as reciprocals of serum dilutions. $0=$ no detectable antibodies. 
Table 2. Homologous and heterologous CFT titres in pigs given an aerosol with reference serotypes 2, 3, 4 and 7 of $H$. parasuis and challenged with serotype 5, strain 4800 .

\begin{tabular}{|c|c|c|c|c|c|c|c|c|c|c|c|}
\hline \multirow{2}{*}{$\begin{array}{l}\text { Sera from } \\
\text { pig No }\end{array}$} & \multirow{2}{*}{$\begin{array}{c}\text { Aerosol } \\
\text { with } \\
\text { serotype }\end{array}$} & \multicolumn{5}{|c|}{$\begin{array}{c}\text { Titres after } \\
\text { aerosol to serotypes }\end{array}$} & \multicolumn{5}{|c|}{$\begin{array}{l}\text { Titres after challenge } \\
\text { with serotype } 5 \text { to serotypes }\end{array}$} \\
\hline & & 2 & 3 & 4 & 7 & $5^{* *}$ & 2 & 3 & 4 & 7 & $5^{* *}$ \\
\hline 15 & 2 & $* 32$ & 0 & 16 & 32 & 32 & 32 & 0 & 32 & 32 & 32 \\
\hline 16 & 2 & 32 & 0 & 32 & 32 & 64 & 32 & 0 & 64 & 32 & 64 \\
\hline 17 & 3 & 0 & 16 & 0 & 0 & 0 & 0 & 16 & 0 & 0 & 0 \\
\hline 18 & 3 & 0 & 32 & 0 & 0 & 0 & 0 & 32 & 0 & 0 & 0 \\
\hline 19 & 4 & 16 & 0 & 32 & 32 & 32 & 16 & 0 & 16 & 16 & 16 \\
\hline 20 & 4 & 16 & 0 & 16 & 16 & 16 & 16 & 0 & 16 & 16 & 16 \\
\hline 21 & 7 & 32 & 0 & 64 & 64 & 32 & 16 & 0 & 32 & 32 & 32 \\
\hline 22 & 7 & 32 & 0 & 32 & 64 & 32 & 16 & 0 & 32 & 32 & 32 \\
\hline
\end{tabular}

The challenge control pig (No 23) died day 4 after aerosol.

*: Titres are given as reciprocals of serum dilutions.

$0:$ no detectable antibodies.

**: strain 4800 .

trol became anorectic and dyspneic day 3 p.i. and died the following day.

Pathological findings. At necropsy, pig No 23 had a fibrinous pleuritis and excessive serofibrinous fluid in some joint cavities. No other pig had any macroscopic lesions when they were killed 5 days after exposure to strain 4800 (serotype 5).

Bacteriological findings. H parasuis was re-isolated from the pleura of pig No 23 but not from any other of the pigs.

Serological findings. The pigs were seronegative before inoculation but, after exposure to the aerosol, most titres were higher than those seen in experiment 1 (1:16 to $1: 64)$ and showed the same pattern of cross-reaction between serotypes 1 and 3 and between serotypes 2, 4, 5, 6 and 7. Titres were not significantly increased after challenge with strain 4800 (Table 2). Control pig No 23 had not developed an antibody response by the time it died 4 days p.i. (omitted in Table 2).

\section{Discussion}

Intranasal inoculation of SPF pigs with large doses of one or other of the 7 serotypes of $H$. parasuis showed that only the reference strains of serotypes 1 and 5 were able to produce the clinical signs and pathological changes typical of Glässer's disease. These results showed a clear difference in pathogenicity among the reference serotypes and confirm the observation of others (Kielstein et al. 1990, Morozumi \& Nicolet 1986a, Rapp-Gabrielson et al. 1990) that the strains that cause Glässer's disease belong to serotypes 1 and 5 . Morozumi \& Nicolet (1986b) suggested a correlation between the peptide pattern of $H$. parasuis strains and pathogenicity, the pathogenic strains occurring amongst those with a PAGE type II pattern. The results obtained in this study correspond with this observation, since both serotype 1 and 5 have a PAGE type II pattern. On the other hand, although the reference strain of serotype 2 also has a PAGE type II pattern (Morozumi \& Nicolet $1986 \mathrm{~b}$ ) it was apathogenic for the SPF pigs in the present study. The presence of a capsule is 
generally considered to be an important virulence factor. However, the work reported here has not clarified the issue of the capsule for virulence in $H$. parasuis, since both the virulent serotype 1 and the avirulent serotype 2 are capsulated (Morozumi \& Nicolet 1986b). Further studies of the virulence factors of this organism are clearly needed.

Earlier studies have shown that circulating antibodies can be demonstrated by the CFT approximately 10 days after infection with $H$. parasuis (Nielsen 1980). Although serotypes $2,3,4,6$ and 7 , as used in this study, were unable to provoke disease, intranasal inoculation with them resulted in the appearance of circulating antibodies. Judged from the serological response, serotypes 1 and 3 seem to represent one antigenically related group and serotypes 2, 4, 5, 6 and 7 another. It is noteworthy that both serotypes 1 and 5 - the only ones that were able to induce disease - share antigenic determinants with non-pathogenic serotypes. This seems to suggest that the antibodies demonstrable by the CFT are not a response to the virulence factors of the organism.

When SPF pigs were given an aerosol with one of each of the apathogenic $H$. parasuis serotypes 2, 3, 4 and 7 they resisted challenge 2 weeks later with a virulent Danish strain of serotype 5. All the pigs developed humoral, complement-fixing antibodies after the aerosol. The titre of these antibodies was unchanged after the challenge, suggesting that the challenge strain had not penetrated the nasal mucosa. The cross-immunity between the various serotypes revealed in this study is not associated with these CFT titres, since the pigs given the aerosol with serotype 3 had titres only to this serotype but nevertheless resisted challenge with serotype 5 . It seems possible that intranasal inoculation induces mucosal antibody to a wide spectrum of anti- gens, among which are common antigens which result in cross-protection. In this respect, the situation may be analogous to that seen after infection of pigs with Actinobacillus pleuropneumoniae, which induces cross immunity between a variety of serotypes of this organism after a natural respiratory infection but not after parenteral injection (Nielsen 1979). Parenteral vaccination with a serotype 5 strain of $H$. parasuis in previously unexposed pigs has been used with excellent results. Thus, clinical symptoms were not observed in vaccinated pigs transferred to a herd suffering from acute outbreaks caused by this serotype. In contrast, unvaccinated pigs transferred to the same herd had a morbidity rate of 50\% (Nielsen \& Danielsen 1975). In view of the fact that new virulent $H$. parasuis serotypes were recently proposed and several of these may be present in one country (Kielstein \& Rapp-Gabrielson 1991) studies are clearly needed to determine if parenteral vaccination will elicit a serotype specific protection only, as is the case with A pleuropneumoniae (Nielsen 1984).

$H$. parasuis is frequently isolated from healthy pigs (Møller \& Kilian 1990). Among such isolates there may be pathogenic strains since serotype 1 was originally isolated from the nasal cavity of a healthy pig (Morozumi \& Nicolet 1986b). This was further substantiated by Morozumi et al. (1981) who reproduced Glässer's disease in SPF pigs with strains which were carried in clinically normal, conventional pigs. Also Smart et al. (1986), by SDS PAGE of restriction endonuclease fragments, showed that some strains isolated from Glässer's disease had identical patterns to nasal isolates of $H$. parasuis from healthy pigs. Future studies of the factors that enable the organism to produce clinical disease might provide useful information for identification of pathogenic strains by routine. 


\section{References}

Baehler JF, Burgisser H, De Meuron PA, Nicolet J: Haemophilus parasuis infection in pigs. Schweiz. Arch. Tierheilk. 1974, 116, 183-188.

Biberstein EL, White DC: A proposal for the establishment of two new Haemophilus species. J. Med. Microbiol. 1969, 2, 75-78.

Casey $H L$ : Standardized diagnostic complement fixation method and adaption to micro test. Public Health Monograph No 74. U.S. Department of Health, Education and Welfare, Washington D.C. 1965.

Glässer K: Untersuchungen über die Schweineseuche mit besonderer Berücksichtigung ihrer Ätiologie und Pathologie. (Studies on polyserositis in swine with special reand to etiology and pathology). Deutsch. Tierärztl. W.schr. 1910, 18, 729-733.

Kielstein P, Rosner H, Müller H: Relationship between serology, virulence and protein patterns of Haemophilus parasuis. Proc. Int. Pig Vet. Soc., Lausanne, 1990, p. 180.

Kielstein P, Rapp-Gabrielson VJ: Designation of 15 serovars of Haemophilus parasuis based on immunodiffusion using heat-stable antigen extracts. Proc. Conf. Research Workers in Animal Disease. 1991, p. 7.

Miniats OP., Smart NL, Metzger K: Glässer's disease in South Western Ontario. I. A retrospective study. Proc. Int. Pig Vet. Soc., Barcelona, 1986, p. 279.

Morozumi T, Hiramune T, Kobayashi K: Glässer's disease in piglets produced by intraperitoneal inoculation with Haemophilus parasuis. Nat. Inst. Anim. Health Q., 1981, 21, 121-128.

Morozumi T, Nicolet J: Some antigenic properties of Haemophilus parasuis and a proposal for serological classification. J. Microbiol. 1986a, 23, 10221025.

Morozumi T, Nicolet: Morphological variations of Haemophilus parasuis strains. J. clin. Microbiol. 1986b, 23, 138-142.

Møller K, Killian M: V-factor dependent members of the family Pasteurellaceae in the porcine upper respiratory tract. J. clin. Microbiol. 1990, 28, 27112716.

Nicolet J: Sur l'hemophilose du porc. III. Differenciation sérologique de Haemophilus parahaemolyticus. (Pleuropneumonia in pigs. Serological differentiation of Haemophilus parahaemolyticus). Zentralbl.Bakteriol. 1971, 216, 487-495.

Nicolet J, Morozumi T Bloch J: Proposal for a sero- logical classification of Haemophilus parasuis. Proc. Int. Pig Vet. Soc., Barcelona 1986, p. 260.

Nielsen $R$, Danielsen V: An outbreak of Glässer's disease. Studies on etiology, serology and the effect of vaccination. Nord. Vet.-Med. 1975, 27, 20-25.

Nielsen R: Haemophilus parahaemolyticus serotypes. Pathogenicity and cross immunity. Nord. Vet.Med. 1979, 31, 407-413.

Nielsen R: Glässer's disease. Clinical and epidemiological field studies. Proc. Int. Pig Vet. Soc. Copenhagen 1980, p. 192.

Nielsen R: Haemophilus pleuropneumoniae infection in pigs. Thesis, Copenhagen, Denmark. 1982.

Nielsen R: Haemophilus pleuropneumoniae serotypes. Cross protection experiments. Nord. Vet.Med. 1984, 36, 221-234.

Rapp-Gabrielson VJ, Gabrielson, DA, Schamber GJ: Comparative virulence of Haemophilus parasuis isolates for guinea pigs. Proc. Int. Pig Vet. Soc., Lausanne, 1990, p. 82.

Smart N.L, Miniats OP, Friendship RM, Mac Innes J: Glässer's disease in South Western Ontario. II. Isolation of Haemophilus parasuis from SPF and conventional swine herds. Proc. Int. Pig Vet. Soc., Barcelona 1986, p. 280.

\section{Sammendrag}

Haemophilus parasuis serotyper: Unders $\varnothing$ gelser over patogenitet og immunitet.

Intranasal podning af SPF grise med Haemophilus parasuis serotyperne 1-7 viste, at kun serotyperne 1 og 5 var i stand til at fremkalde de kliniske og patologiske forandringer, der er karakteristiske for Glässer's syndrom. Selv om serotyperne 2, 3, 4, 6 og 7 ikke var i stand til at fremkalde sygdom, udløste de imidlertid et serologisk respons, der blev påvist i form af komplementbindende antistoffer i serum. De serologiske undersøgelser viste, at serotyperne 1 og 3 har fælles antigene determinanter, der er forskellige fra de determinanter, der deles af typerne 2, 4, 5, 6 og 7 .

Grise, der blev podet med en aerosol af de apatogene typer 2, 3, 4 eller 7, var beskyttet fuldstændigt mod challenge 2 uger senere med en virulent serotype 5 isoleret fra et besætningsudbrud. Alle 7 serotyper synes således at have fælles antigene determinanter, der er i stand til at udløse krydsimmunitet på luftvejsslimhinden. Yderligere undersøgelser er påkrævet for at afklare, om krydsimmunitet også kan opnås ved parenteral vaccination eller om denne $\mathrm{i}$ lighed med forholdene ved Actinobacillus pleuropneumoniae kun beskytter mod infektion med den homologe serotype.

(Received November 6, 1992; accepted January 14, 1993).

Reprints may be requested from: R. Nielsen, National Veterinary Laboratory, DK-1790 Copenhagen V, Denmark. 